\title{
The Effect of Capital Adequacy Ratio, Net Interest Margin and Non-Performing Loans on Bank Profitability: The Case of Indonesia
}

\author{
Pasaman Silaban $^{1}$
}

\begin{abstract}
:
The purpose of this study is to test and determine the Bank's health level consisting of capital adequacy ratio (CAR), net interest margin (NIM), and non performing loans (NPL) partially or simultaneously on bank profitability based on data from the Indonesian Stock Exchange.
\end{abstract}

The population of this study is all state and private banks listed in the Indonesian Stock Exchange (ISE) amounting to 40. Observations are conducted from 2012 to 2016.

The results indicate that capital adequacy ratio (CAR) does not have a significant effect on bank profitability. Net interest margin (NIM) improves the growth of bank profitability.

This can happen because NIM has a component of net interest in its ratio. Non performing loans (NPL) have a negative effect on bank profitability.

Keywords: Capital adequacy ratio, net interest margin, non performing loan, profitability.

\footnotetext{
${ }^{1}$ Professor at the Faculty of Economics of Universitas HKBP Nommensen, Medan, North Sumatra, Indonesia.Email: pasamansilaban@yahoo.co.id
} 


\section{Introduction}

Banks are the most important financial institutions and greatly affect both micro and macro economics. Banks have a large share of the market, which is about 80 percent of the overall financial system (Abidin, 2007). Given the importance of the role that banks play in Indonesia, decision makers need to perform adequate performance evaluations.

The level of health of the bank is important for maintaining the stability of the national financial system (Thomson, 1991). The level of health of banking is an early warning system of surveillance for the bank's performance in the present and its prospects in the future. Bank health is an early warning system that is useful to describe the financial conditions, weakness and strengths of financial aspects of the banking sector (Sinkey, 2002).

Indicators in the assessment of the level of bank health used in this study are limited by the factors of assessment of bank health which are quantitative in nature, and indicators of the assessment of the level of health of the bank that is easily accessible by the parties concerned to be considered in decision making such as capital adequacy ratio (CAR), non performing loans (NPL), and net interest margin (NIM).

To assess bank soundness, the capital adequacy ratio (CAR) is used as an indicator to assess capital. This is used to measure the adequacy of capital owned by banks to support assets that contain or cause risks. If the car value is high it means that the bank is able to finance the operation and this favorable circumstance may contribute substantially to its profitability (ROA) (Dendawijaya, 2003; Parwati et al., 2017).

Net interest margin (NIM) is used to measure the ability of bank management to generate interest income by considering the performance of banks to disburse loans, given that the operational income of banks is highly dependent on the difference between interest and credit disbursed. The greater the NIM achieved by the bank, the higher the interest income on earning assets managed by the bank concerned, thereby increasing the bank's profit (ROA) (Hasibuan, 2007; Fatimah, 2017).

Debt equity ratio (DER) is the ratio used to measure the ability of banks to cover part or all of their debts to the government and investors who invest their capital both in the long and short term with funds derived from their own capital (Margaretha, 2004). Profitability is the most appropriate indicator to measure the performance of a bank. The measures of profitability commonly used in the banking industry are return on equity (ROE) and return on assets (ROA). Return on assets (ROA) focus on the company's ability to earn earnings by its operations, while return on equity (ROE) measures the return earned from the investment of the company owner in the business involved (Siamat, 2002; Isnarno, 2018). 
The development of return on assets (ROA) of banks in the banking industry listed in the Indonesian Stock Exchange (ISE) in the period 2012-2016 shows significant fluctuations.

Based on the background of the above problem, this research is aimed to develop previous research and to explain the effect of capital adequacy ratio, net interest margin and non performing loans on banking profitability in the Indonesian Stock Exchange (ISE) in the period from 2012 to 2016.

\section{Theory and Development of Hypotheses}

\subsection{Capital Adequacy Ratio}

Capital adequacy ratio is the capital adequacy that indicates a bank's ability to maintain sufficient capital and management capability of a bank to identify, measure, monitor, and control risks that arise and may affect the amount of bank capital (Kuncoro and Suhardjono, 2002). Capital adequacy ratio (CAR) is a ratio that shows how much the total assets of banks that contain the risk (credit, inclusion, securities, bills in other banks) are also financed from their own capital other than the funds obtained from other sources outside the bank. The minimum CAR rate set by the Central Bank of Indonesia is $8 \%$. If a bank's CAR is less than $8 \%$ it means that the bank is not able to absorb any losses that may arise from the business activities of the bank. Meanwhile, if the CAR is greater than $8 \%$ it indicates that the concerned bank is getting solvable.

With the increasing level of solvency of a bank, it will indirectly affect the improvement of bank's performance, because the losses borne by the bank can be covered by the capital owned by the bank. This ratio can be formulated as follows:

$$
C A R=\frac{\text { Bank capital }}{\text { Total ATMR }}
$$

Capital is found to be associated with positive profitability (Berger, 1995; Naceur and Omran, 2011). Berger (1995) finds a strong positive relationship between capital and earnings. Altunbas et al. (2007) find that inefficient European banks appear to hold more capital. Goddard et al. (2010) explore a negative relationship between the capital ratio and profitability. Another literature stream concentrating on the relationship between capital and profitability focuses on the macro prospective, structure-conduct-performance hypothesis (SCP). The results of such research show that operating performance is significantly related to market structure. Market structure, which refers to the degree of market concentration within an industry, represents the degree of competition within the specific industry.

Prasanjaya and Ramantha (2013) analyzed the effect of capital adequacy ratio (CAR), return on assets (ROA), loans to deposits ratio (LDR), and the size of the 
company to profitability of banks listed in the Indonesian Stock Exchange. Based on the above explanations, the first hypothesis is formulated and developed as follows:

H1: Capital adequacy ratio (CAR) has a significant positive effect on the profitability (ROA) of banking in Indonesia.

\subsection{Net Interest Margin (NIM)}

Net interest margin (NIM) is a reflection of market risk arising from changes in market conditions where such changes could harm banks (Hasibuan, 2007). The NIM is also used to measure the bank's management capability to generate interest income by taking into account the performance of banks to disburse loans, given that the operational income of banks is highly dependent on the difference between interests and credit disbursed (Mahardian, 2008).

According to Bank of Indonesia circular letter no. 3/30dpnp dated December 14, 2001, NIM is measured by comparing net interest income to earning assets. The greater the NIM, the higher the interest income on earning assets managed by the bank. If that is the case then it shows better financial performance of the bank (Almilia and Herdiningtyas, 2005). The ratio of net interest margin is calculated by the following formula:

$$
N I M=\frac{\text { Net interest income }}{\text { Total assets }}
$$

Measuring a bank's profitability, net interest margin (NIM) is the most commonly used measure in these studies, due to the importance of interest income and interest expense, since they are the main traditional function of banks' major operations, and for the substantial amount of their operating income (Gunter et al., 2013). A handful of studies which detect the determinants of bank profitability have been made by Ho and Saunders (1981), Hamadi and Awdeh (2012) and Ayaydin (2014).

Some studies focused on cross-countries results, whereas others focused on individual countries due to time period, laws and regulations differences, databases, economies, and different variables. One common goal among these studies is to define the determinants of banks' profitability. For example, Osborne (1980) finds a strong positive relationship between capital adequacy ratio and profitability of US banks during 1980s. However he considered that the relationship should be negative under certain situations (Zahra et al., 2017). Based on the above explanations, the second hypothesis is formulated and developed as follows:

H2: Net interest margin (NIM) has a significant positive effect on the profitability (ROA) of banking in Indonesia. 


\subsection{Non Performing Loans (NPL)}

Based on the Bank of Indonesia circular letter no. 3/30 dpnp dated December 14, 2001, non performing loans (NPL) is measured by a ratio that compares bad credit to total disbursed loans. The high value of NPL will enlarge costs and potentially cause bank losses. Loans in this case are credits granted to third parties excluding credit to other banks. Non-performing loans are credits with poor quality, doubtful, and loss. In accordance with the rules set by the Bank of Indonesia, the amount of good NPL is less than $5 \%$. This ratio is formulated as follows:

$$
N P L=\frac{\text { Total nonperforming loans }}{\text { Total credit disbursed }}
$$

Brown and Moles (2014) define credit risk as the risk related with the loans; banks lend to the borrower and normally charge a fee against it. The banks redistribute its finance in the form of debt to borrowers, which is needed to be paid back by the distributors. However, there is no assurance of the fact that such amount would be re-paid by the borrowers and the risk of default is always there for the banks on lend loans. Financial researchers and analysts regard such risk as credit risk.

Aduda and Gitonga (2011) further stated that generally financial institutions adopt a range of techniques for the mitigation of their credit risk. According to them, the commonly used techniques include collateral, guarantees, and net-off loans. These loans are net-off with the help of receipt, leading to decreased credit risk. In other studies, insurance, factoring, debt compilation, surety bonds, and letter of credit (LC) are recognized as extensively used methods of risk management (Aduda and Gitonga, 2011). According to Vaidyanathan (2013) the reason behind development and implementation of range of credit risk techniques can be confirmed from the fact that better and improved system for credit risk management can lead to timely risk evaluation, appropriate organizational setup and effective system of credit monitoring (Simanjuntak and Pangestuti, 2017; Suroso et al., 2017). Several latest researchers have also dug into the same topic and other related topics (Aduda 2011). They have found positive relationship between credit risk management and profitability of commercial banks in Sweden (Kolapo, 2012; Din et al., 2017) assessing the effect of credit risk management on the profitability of commercial banks and found that banks' profitability is not affected by credit risk management. Therefore the third hypothesis is formulated and developed as follows:

H3: Non-performing loans (NPL) have a significant positive effect on the profitability (ROA) of banking in the Indonesia.

\subsection{Profitability}

Profitability is the company's ability to generate profits and to measure the level of operational efficiency and efficiency in using its assets (Chen, 2004). To measure 
profitability, some indicators can be used such as operating profit, net income, return on investment / asset, and return on owner's equity. Ang (1997) revealed that the profitability ratio shows the company's success in generating profit. The company's ability to generate profits in its operational activities is a key point in corporate performance appraisal. In addition to being an indicator of the ability of the company to fulfill its obligations to its funders, the company's profit is also an element in determining the value of the company (Andriyansah et al., 2017).

In past studies, the researchers for determining profitability use several measures. Some use qualitative performance aspects while other associate financial quantitative indicators with profitability. Brealey and Myers (2003) have stressed that there are diverse significant measures that could be used in investigating the profitability of a business institution. According to them, these include net profit ratio, ratio of return on assets (ROA), and ratio of return on equity (ROE). The authors discussed the procedure introduced by past researcher Cole in 1972. Cole (1972) put forth the ratio analysis method for the evaluation and the assessment of the banks' performance.

According to this process, an investigator of bank's profitability must focus upon the source and size of the financial institution in relation to the amount of risk, that has accepted. Cole believed that income statement of a bank is the core and foremost source for driving the measures of performance for it (Siallagan et al., 2017). Therefore, he stated that there are several measures of profitability. One of such measure is the ratio of net income to equity, i.e., the accounting return on equity (ROE). ROE can also be used for serving as a target measure for determining profitability at the overall level (Zahra, 2017).

In most research papers relating to this study the profitability is measured in the form of ratios which are normally reported by commercial banks in their annual reports. Bentum (2012) claims that the use of profitability ratios are not influenced by changes in price levels. And it is said to be the most appropriate way of measuring profitability as one make use of time series analysis. This is because the real value of profits cannot be affected by the varying inflation rates for one to realize how well a bank is performing which is much more useful to consider the return on assets (ROA) and the return on equity (ROE). For the purposes of this study, profitability is measured using return on assets (ROA). According to Van Horne (2005), return on assets (ROA) is the ability of a bank's management in obtaining profit as a whole. The formula used is:

$$
R O A=\frac{\text { Net profit }}{\text { Total assets }}
$$

\section{Research Method}

\subsection{Type and Nature of Research}


The research used in the present study is a comparative causal type that aims to analyze the effects of independent variables on the dependent variable. The independent variable (x) in this study is the health level of the bank (CAR, NIM and NPL), while profitability (ROA) is the dependent variable. The research is descriptive explanatory, that is research which aims to explain the position of the variables studied and the relationship between one variable with other variables.

\subsection{Type and Sources of Data}

The types and sources of data used in this study are secondary data, i.e., data obtained by documentation studies, from books, research journals, magazines, and internet sites. To support this research data are also obtained from the financial statements of state and private banks listed in the Indonesian Stock Exchange from 2012 to 2016 . The population in this study is all the state and private banks listed in the Indonesian Stock Exchange (ISE). A total of 40 banks formed the population, and the non-probability sampling method was used for sampling by purposive sampling in nature. The criteria to be sampled are as follows:

1. A bank listed in the Indonesian Stock Exchange from 2012 to 2016;

2. A bank that publishes complete financial statements and has been audited from 2012 to 2016 and presents the complete data used to calculate the values of ROA, CAR, NIM and NPL.

Based on the above criteria, 27 banks were obtained as samples with 135 observations over a 5 year period.

\subsection{Data analysis and discussion}

Descriptive statistics provide an overview of data reviewed by value of average (mean), standard deviation (variance), maximum value, and minimum value. Analysis of research data of banking companies listed in the Indonesian Stock Exchange for the period 2012-2016 can be seen in Table 1 below. Using 135 research data and involving 27 companies for 5 years from 2012 to 2016, the following results are obtained:

Table 1. Data Descriptive Statistics

\begin{tabular}{|l|c|c|c|c|c|}
\hline & ROA & CAR & NIM & NPL & LDR \\
\hline Mean & 0.011 & 0.124 & 9.085 & 0.026 & 0.868 \\
\hline Median & 0.012 & 0.054 & 3.561 & 0.022 & 0.839 \\
\hline Maximum & 0.044 & 1.979 & 118.433 & 0.311 & 1.996 \\
\hline Minimum & -0.095 & 0.003 & 0.175 & 0.000 & 0.345 \\
\hline Std. Dev. & 0.017 & 0.251 & 16.958 & 0.032 & 0.289 \\
\hline Skewness & -3.475 & 4.917 & 4.195 & 5.974 & 1.931 \\
\hline Kurtosis & 21.022 & 30.688 & 23.021 & 51.799 & 7.569 \\
\hline Jarque-Bera & 2098.764 & 4856.072 & 2650.670 & 14198.170 & 201.323 \\
\hline
\end{tabular}




\begin{tabular}{|l|c|c|c|c|c|}
\hline & ROA & CAR & NIM & NPL & LDR \\
\hline Probability & 0.000 & 0.000 & 0.000 & 0.000 & 0.000 \\
\hline Sum & 1.552 & 16.705 & 1226.498 & 3.527 & 117.226 \\
\hline Sum Sq.Dev. & 0.037 & 8.452 & 38535.940 & 0.133 & 11.221 \\
\hline Observations & 135 & 135 & 135 & 135 & 135 \\
\hline
\end{tabular}

$\checkmark$ The variable ROA with an average value of 0.011 is the object of the research, with a standard deviation of 0.017 indicating that the data is relatively homogeneous.

$\checkmark$ The variable CAR with an average value of 0.124 is the object of the research, with a standard deviation of 0.251 indicating that the data is relatively homogeneous.

$\checkmark$ The variable NIM with an average value of 9.085 is the object of the research, with a standard deviation of 16.958 indicating that the data is relatively variable or heterogeneous.

$\checkmark$ The variable NPL with an average value of 0.026 is the object of the research, with a standard deviation of 0.032 indicating that the data is relatively homogeneous.

\section{Hypothesis Testing}

\subsection{Multiple Linear Regression Analysis}

The hypothesis of this study was tested using data estimated by multiple regression analysis. The estimation results showed coefficients between independent and dependent variables as presented in Table 2. Based on the estimation results, the regression equation can be determined as follows:

$$
\mathrm{ROA}=0.009+0.001 \mathrm{CAR}+0.202 \mathrm{NIM}-0.270 \mathrm{NPL}+\varepsilon
$$

It can be seen that CAR and NIM variables (in lag form) have positive effects on the dependent variable ROA and both are significant at 5\% significance level, while variable NPL (in lag form) has a significant negative effect on banking profitability. It is shown, by the regression equation obtained, that the variables having the strongest positive effect and being significant on banking profitability (ROA) are net interest margin (NIM) with regression coefficient of 0.202 and non-performing loans (NPL) with regression coefficient of -0.270 while capital adequacy ratio (CAR) with regression coefficient of 0.001 but not significant.

Table 2. Multiple Linear Regression Analysis Coefficients ${ }^{a}$

\begin{tabular}{|c|c|c|c|c|c|}
\hline \multirow[t]{2}{*}{ Model } & \multicolumn{2}{|c|}{$\begin{array}{c}\text { Unstandardized } \\
\text { Coefficients }\end{array}$} & $\begin{array}{c}\text { Standardized } \\
\text { Coefficients } \\
\end{array}$ & \multirow[t]{2}{*}{$\bar{T}$} & \multirow[t]{2}{*}{ Sig. } \\
\hline & $\mathrm{B}$ & Std. Error & Beta & & \\
\hline $1 \quad$ (Constant) & .009 & .004 & กา & 2.198 & .030 \\
\hline
\end{tabular}


66

\begin{tabular}{|l|r|r|r|r|r|}
\hline Lag_NIM & .202 & .000 & .323 & 4.302 & .000 \\
Lag_NPL & -.270 & .043 & -.511 & -6.281 & .000 \\
\hline
\end{tabular}

A. Dependent Variable: Lag_ROA

Source: Secondary Data Processed by the author.

\subsection{Coefficient of Determination}

The coefficient of determination $\left(\mathrm{R}^{2}\right)$ substantially measures the extent of the model's ability to explain the variation of the dependent variable. The higher the value of the coefficient of determination, the higher the model's ability to explain the variation of the dependent variable (Table 3).

Table 3. Coefficient of Determination: Model summary ${ }^{b}$

\begin{tabular}{|l|r|r|r|r|r|}
\hline Model & $\mathrm{R}$ & R square & \multicolumn{1}{c|}{$\begin{array}{c}\text { Adjusted } \mathrm{r} \\
\text { square }\end{array}$} & $\begin{array}{c}\text { Std. Error of the } \\
\text { estimate }\end{array}$ & Durbin-watson \\
\hline 1 & $.707^{\mathrm{a}}$ & .557 & .534 & .0133383 & 1.895 \\
\hline
\end{tabular}

A. Predictors: (constant), lag_nim, lag_npl, lag_car

B. Dependent variable: lag_roa

Source: Secondary data processed by the author.

Table 3 shows that the value of the coefficient of determination R2 adjusted is 0.534. This means that $53.40 \%$ of the dependent variable, i.e. profitability, can be explained by the three variables in the regression line, i.e. CAR, NIM and NPL, while the remaining $46.60 \%$ is explained by other variables not included in the model.

\subsection{T-test (partial test)}

The partial regression model test is used to determine whether or not each independent variable forming the regression model individually influences the dependent variable. The test of each research hypothesis is done by considering the value of regression coefficient and the significance level of each estimator. The following are the results of testing the research hypotheses.

\section{A. Testing Hypotheses 1:}

The first hypothesis in this study predicts that the capital adequacy ratio (CAR) has a positive but not significant effect on return on assets. The results show that the regression coefficient is 0.001 with significance level 0.797 and the value of tcounted as 0.257 . This empirical evidence does not support the research hypothesis that is clearly visible by the sign of the regression coefficient, the probability value is greater than $5 \%$, and the value of the t-counted is smaller than the value of t-table which is 1.6567. Thus it can be concluded that $\mathrm{H} 1$ is rejected. The results of this study are in accordance with other studies conducted by Gul et al. (2011), Akhtar et al. (2011) and Fatimah et al. (2018). 
Therefore variable CAR has no effect on the changes in earnings. This is probably because the capital owned by the bank is only used to meet the requirements of the Bank of Indonesia. Another thing that might happen is that banks invest more capital in productive assets, while they are less cautious in channeling funds to real sector, and provide less supervision to bad debts. So, some of the bank's capital (CAR) is actually used to cover risks.

\section{B. Testing Hypotheses 2:}

The second hypothesis in this study predicts that net interest margin (NIM) has a significant positive effect on return on assets. The results of data processing show that the regression coefficient is 0.202 with probability 0.000 and the value of $t$ counted is 4.302. This empirical evidence reinforces the research hypothesis shown by the sign of the regression coefficient, the value of probability is smaller than $5 \%$ and the value of the t-counted is greater than the value of t-table which is 1.6567 . Thus it can be concluded that $\mathrm{H} 2$ is accepted. The results of this study are in accordance with a study conducted by Saksonova (2014).

\section{Testing Hypothesis 3:}

The third hypothesis in this study predicts that non-performing loans (NPL) have a significant negative effect on return on assets. The results of data processing show that the regression coefficient is -0.270 with probability of 0.000 and the value of $t-$ counted is -6.281 . This empirical evidence supports the research hypothesis shown by the sign of the regression coefficient, the probability value is smaller than $5 \%$, and the value of $t$-counted is greater than the value of t-table which is 1.6567. Thus, it can be concluded that $\mathrm{H} 3$ of research is accepted. The results of this study are in accordance with a study conducted by Akhtar et al. (2011).

\section{Conclusions}

Based on the data analysis and discussion above, the following conclusions are obtained:

a. Capital adequacy ratio (CAR) does not have a significant effect on banking profitability. Variable CAR has no effect on earnings change. It may explain by the fact that the capital owned by the bank is only used to meet the requirements of the Bank of Indonesia. Another thing that may happen is because the banks invest more in productive assets but less cautious in channeling funds to the real sector, and provide less supervision of financing that stalled so that some of the bank's capital (CAR) is actually used to cover risk.

b. Net interest margin (NIM) has the effect to improve the growth of bank profitability. This can happen because NIM has a net interest component in its ratio. High NIM ratios tend to indicate high profit growth as well.

c. Non performing loans (NPL) have a negative effect on bank profitability. The explanation that can be given to support this research is that during the period of study (2009-2013) the banking business condition were very abnormal because it was affected by the crisis of 2008. Non-performing loans (NPL) have no 
significant effect on profitability. This abnormal condition causes the greater number of problem loans faced by the bank so that the greater the number of banks experiencing troubled conditions, the smaller the profit earned.

\section{References:}

Abidin, Z. 2007. Performance efficiency in commercial banks. Proceeding, psychology, economics, literature, architects and civil, 2.

Aduda, J. and Gitonga, J. 2011. The relationship between credit risk management and profitability among the commercial banks in Kenya. Journal of Modern Accounting and Auditing, 7(9), 934-946.

Akhtar, M.F. 2011. Factors influencing the profitability of islamic banks of Pakistan. International research journal of finance and economics, 66.

Almilia, 1.S. and Herdiningtyas, W. 2005. Analysis of camel ratio to prediction of problem condition in banking institution period 2000-2002. Journal of Accounting and Finance, 7(2).

Andriyansah, F., Zahra, S., Parwati, S.M., Kurniawan, S., Simanjuntak, H., Siallagan, H. and Mulatsih, R. 2017. Does accounting control system boost marketing capabilities? International journal of civil engineering \& technology, 8(8), 209-216.

Altunbas, Y.S., Carbo, E., Gardener, P.M. and Molyneux, P. 2007. Examining the relationships between capital, risk and efficiency in european banking. European financial management, 13(1), 49-70.

Anthonasoglou, A., Brissimis, S. 2005. Bank spesific industry, and specific makroekonomic determinant of bank profitabilitas. Working paper, Bank of Greece. No. 25.

Ayaydin, H., Karakaya, A. 2014. The effect of bank capital on profitability and risk in turkish banking. International journal of business and social science, 5(1).

Bentum, W. 2012. Determinants of profitability of the commercial banks in Ghana during the recent years of global financial crisis. Aarhus.

Berger, A.N. and Bouwman, C.H.S. 2013. How does capital affect bank performance during financial crises? Journal of financial economics, 109, 146-176.

Berger, A.N. 1995. The relationship between capital and earnings in banking. Journal of money, credit and banking, 27(2), 432-456.

Brealey, R.A., Myers, S.C. 2003. Principles of corporate finance. McGraw hill.

Brown, K., Moles, P. 2014. Credit risk managment. Edinburgh business school.

Cole, D. 1972. A return on equity model for banks. The bankers' magazine.

Chen, R. and Wong, A.K. 2004. The determinants of financial health of Asian insurance companies. The journal of risk and insurance, 71(3), 469-499.

Dendawijaya, L. 2003. Banking management. Jakarta. Publisher ghalia Indonesia.

Din, M.S. Paranoan, R., Masdar, H., Siallagan, S. and Achmad, T. 2017. Public accountability based on the value of local wisdom. International journal of civil engineering and technology, 8(8), 1046-1053.

Fatimah, F., Rosadi, D., Hakim, R.B.F. and Alcantud, J.C.R. 2017. A social choice approach to graded soft sets. In fuzzy systems (fuzz-ieee), 2017 ieee international conference on (pp. 1-6). Ieee.

Fatimah, F., Rosadi, D. and Hakim, R.B.F. 2018. Probabilistic soft sets and dual probabilistic soft sets in decision making with positive and negative parameters. In journal of physics: conference series (vol. 983, no. 1, p. 012112). Iop publishing.

Goddard, J. Liu, H., Molyneux, P. and Wilson, J.O.S. 2010. Do bank profits converge? European financial management, doi:10.1111/j.1468-036x.2010.00578.x. 
Gunter, U., Krenn, G. and Sigmund, M. 2013. Macroeconomic, market and bank-specific determinants of the net interest margin in austria. Oesterreichische nationalbank financial stability report, 25.

Hamadi, H., Awdeh, A. 2012. The determinants of bank net interest margin: Evidence from the Lebanese banking sector. Journal of money, investment and banking, 23(23), 85-98.

Ho, T.S., Saunders, A. 1981. The determinants of bank interest margins: Theory and empirical evidence. Journal of financial and quantitative analysis, 16(04), 581-600.

Osborne, M. 1980. Capital and profitability in banking: evidence from US banks. London, Loughborough University School of Business and Economics.

Naceur, S.B. and Omran, M. 2011. The effects of bank regulations, competition, and financial reforms on banks' performance. Emerging markets review, 12, 1-20.

Parwati, N.M.S., Zahra, F., Anfas, A. and Nurdyah. 2017. The effect of self assessment system and fraud detection possibility toward tax evasion behavior. International journal of mechanical engineering \& technology, 8(8), 615-622.

Prasanjaya, A.A.Y., Ramantha, I.W. 2013. Analysis of CAR, ROA, LDR, and company size to profitability bank listed on the stock exchange. E-journal of accounting University of Udayana, 4(1), 230-245.

Saksonova, S. 2014. The role of net interest margin in improving banks' asset structure and assessing the stability and efficiency of their operations. International strategic management conference. Procedia - social and behavioral sciences 150.

Siallagan, H., Rohman, A., Januarti, I. and Din, M. 2017. The effect of professional commitment, attitude, subjective norms and perceived behavior control on whistle blowing intention. International journal of civil engineering and technology, 8(8), 508-519.

Sinkey, J.F. 2002. Commercial bank financial management in the financial-services industry. Prentice hall.

Simanjuntak, R.H. and Pangestuti, R.D. 2017. Enhancing banking performance by reducing risk: A preliminary study on the productive credit-based loan portfolio. International Journal of Applied Business and Economic Research, 15(15), 157-167.

Suroso, A., Anggraeni, A.I. and Andriyansah. 2017. Optimizing SMEs' business performance through human capital management. European Research Studies Journal, 20(4b), 588-599.

Thomson, J.B. 1991. Predicting bank failures in the 1980's. Federal Reserve Bank of Cleveland Economic Review, 1.

Vaidyanathan, K. 2013. Credit risk management for Indian banks. New Dehli, Sage publications India.

Van, Horne 2005. Accounting economics. Translation publisher pt. Gramedia public library Jakarta.

Zahra, F. 2017. The impact of participative budgeting on budgetary slack: A meta-analysis. International journal of mechanical engineering and technology, 8(6), 822-830.

Zahra, F.A., Rohman, A., Chariri, A. and Karim, F. 2017. Does e-procurement solve Indonesia local government budgetary slack through it adaptive culture? International journal of civil engineering and technology, 8(8), 1001-1010. 